\title{
Enteric Bacteria from ready to eat food vended in Amassoma community in Niger Delta and its health implication
}

\author{
${ }^{*}$ Douye V. Zige ${ }^{1}$, Elijah I. Ohimain ${ }^{1}$ and Sridhar, K. C. Mynepalli ${ }^{2}$ \\ ${ }^{I}$ Public Health and Medical Microbiology Research Unit Department of Biological Sciences, Niger Delta \\ University, Wilberforce Island, Bayelsa State Nigeria \\ ${ }^{2}$ Department of Environmental Health Sciences, Faculty of Public Health, College of Medicine, University of \\ Ibadan, Ibadan, Nigeria
}

\begin{abstract}
Food consumption is one important aspect of life, therefore it is necessary to safeguard food from contamination, as contaminated food poses serious public health threat, especially foods that are prepared and sold outside for public consumption. Food handlers infected by several enteropathogens have been implicated in the transmission of many infections to the consumers. This study was conducted to survey the bacteriological quality and prevalence of enteric bacteria in ready to eat foods as very little information available on vended food in Bayelsa State, a coastal area in Nigeria. The study used the spread plate method for the growth of Salmonella spp, E coli, E coli 0157, Proteus sp, Klebsiella on SSA, EMB, Sorbitol Macconkey and Blood Agar with biochemical differentiation using Kigler Iron Agar (KIA) along with Motility, Indole and Urea (MIU) tests. A total of 16 isolates were tested of which salmonella species were (5), E coli (4), E coli 0157 (4), Proteus sp and Klebsiella sp (2) each. The isolates tested against selected antibiotics showed varying degree of susceptibility with total resistance observed in Augmentin, Ceftazidine and Cefuroxime. It is concluded that the isolation of Salmonella and E coli 0157 pose a significant health threat especially among children and the aged, as diarrhoea and typhoid incidence are reportedly high among these age groups. The results further suggest that there is necessity for educational/health orientation programmes for consumers and food vendors on hygiene, food handling and sanitation through awareness creation and capacity building.

Key Words: Street Food, Amassoma, Niger Delta Area, Food Handlers, Food-Borne Illnesses.
\end{abstract}

\section{Introduction}

Food borne illnesses continued to be a major universal public health problem, especially in developing countries due to difficulties in safeguarding food from cross contamination. These low-income countries face the highest burden of diarrheal and other food-borne disease associated with the consumption of contaminated food (Zeru and Kumie, 2007). Transmission of enteropathogenic bacteria are through media contaminated with faeces which include: food, water, nails, and fingers, indicating the significance of faeco-oral transmission route (Gashaw et al, 2008). The risk of food borne illness is considerably caused by biological and to some extent chemical contamination in areas where food is produced, processed and consumed (Käferstein and Abdussalam, 1999). The street food industry plays a very important role in meeting food requirements of travellers and urban dwellers, as it feeds thousands of people daily with foods that are affordable and easily accessible (Tambekar et $a l, 2008)$. The term "street food" however refers to a variety of ready-to eat foods and beverages sold and sometimes prepared in the public (Muleta and Ashenafi, 2001). Street foods may be consumed where it was prepared or bought or sometime taken away and eaten elsewhere (WHO, 1996).

Street food vending in Amassoma community started when the population began to increase with the influx of traders and students from all parts of state and neighbouring States. Several pathogenic microorganisms have been associated with many street vended foods (Omemu et al, 2005). Ready to eat foods (street food) are processed and readily available for purchase and consumption. However, street foods have been implicated in transmission of foodborne diseases (Chomvarin et al, 1993; Gillespie et al, 2000; Fang et al, 2003; Mahale $e t a l, 2008)$. The problems of food safety in developing countries is usually attributed to poor personal hygiene practices during foods processing and packaging (Barro et al, 2002a, 2002b; Mensah et al, 2002). Food vending is common in sub-urban and urban areas than in rural areas.

Amassoma community in southern Ijaw Local Government Area of Bayelsa state in southern Nigeria is a sub-urban community with a university, health institution and a variety of commercial activities. This coastal community neglect waste management and sanitary practices as they dump and defecate directly to rivers, and also fetch from this same water for their domestic activities making the incidence of gastroenteritis rampant in health care centres. Like other urban and sub-urban centres, food hawkers are patronised in large numbers usually in the morning and afternoon hours.

Published literature on food handlers and street vendors is scanty in Bayelsa State, Nigeria. Therefore, this study is conceived to assess prevalence of food borne bacteria in foods sold around Amassoma community. 


\section{Study Location}

\section{Materials And Method}

Amassoma community is located about $40 \mathrm{~km}$ to the South of Yenagoa the State capital. It is situated at $4.97^{0}$ north latitude, $6.11^{\circ}$ east longitude and 79 meters elevation above sea level. The community is bounded by River Nun, the population is heterogeneous and second most populous place in the state, consisting mostly of the native ogboins, students from neighbouring areas, petty traders and businessmen from various parts of the State and others. It hosts higher institutions of learning and Hospital. The communities witness rapid growth and increase in population with the establishment of institution of higher learning. The community lacks sanitary facilities, refuse disposal facilities, pipe borne water, electricity, social and recreational facilities and only a few enjoy boreholes and many buy food and water from vendors. The community however have about 37 eateries (restaurents, and bukkas). foods served in this eateries includes rice (Oryza sativa L) cassava (Manihot esculenta), plantain (Plantago lanceolata), yam (Dioscorea spp), beans (Phaseolus and Vigna spp) noodles, soups etc, these foods are patronised by students and those who visit the community for menial jobs.

\section{Collection of Samples}

Thirty (36) ready to eat food samples were collected from bukkas, restaurants, and roadside food vendors at different points in Amassoma community in Niger Delta, southern Nigeria, the samples are cooked Rice and stew, beans porridge, boiled yam, boiled noodles and fried plantain. foods served in eateries includes rice (Oryza sativa L) eating with pepper soup, jollof and stew, garri an African food from cassava (Manihot esculenta), this food is taken with soups of different kind including ogbono (Irvingia spp) egusi (Cucumeropsis mannii Naudin), okro (Hibiscus esculentus L) etc, plantain (Plantago lanceolata) and yam (Dioscorea spp) that are prepared either by boiling, frying and made as porridge and usually eating along with other food type, especially when its fried. Food storage by vendors are usually in bags that easily been infested my house Rats (Ratus ratus), cockroach (Periplaneta americana,) and other household insects.

Samples of ready to eat food were aseptically transported on a cold ice box to the Department of Medical Microbiology, Federal Medical Centre-Yenagoa, Bayelsa State for analysis within $2 \mathrm{~h}$ of collection.

\section{Isolation and Enumeration of Bacteria}

Ten $(10 \mathrm{~g})$ of each food samples were homogenised with sterile mortar and pestle, the resulting homogenate were aseptically added to $9 \mathrm{ml}$ sterile normal saline and serially diluted up to $10^{-5}$. Using the spread plate technique $1 \mathrm{ml}$ of the dilution was seeded on the following differential and selective media (Eosin Methylene Blue (EMB) agar, Salmonella-Shigella agar (SSA) and observed for blue-black greenish metallic sheen for $E$ coli on EMB and black centred colonies for Salmonella after a 24 h incubation at $37^{\circ} \mathrm{C}$. Other growth observed in plates such as presumptive Proteus sp were streaked on blood agar and observed for swarming. Further identification of $E$ coli strains were inoculated on Sorbitol McConkey agar for the differentiation of enteropathogenic strains such as $E$ coli 0157 and incubated at $45^{\circ} \mathrm{C}$ for $24 \mathrm{~h}$. All presumptive isolates were further identified using Kigler Iron Agar (KIA) media and tested for Motility, Indole and Urea (MIU) formation in tubes incubated for $24 \mathrm{~h}$ at $37^{\circ} \mathrm{C}$. These characteristics of differentiation for the isolated strains were read as described by Cheesebrough (2002) and WHO (2003).

\section{Antibiotic Susceptibility Test}

The Sensitivity of the bacterial isolates to different antibiotics was determined using the Kirby- Bauer disc diffusion technique (Bauer et al, 1996) Discs used contained the following antibacterial agents: Ofloxacin $(5 \mu \mathrm{g})$, Ciprofloxacin $(5 \mu \mathrm{g})$, Gentamicin $(10 \mu \mathrm{g})$, Ceftazidine $(30 \mu \mathrm{g})$, Nitrofuratoin $(300 \mu \mathrm{g})$, Augmentin $(30 \mu \mathrm{g})$, Cefixime $(5 \mu \mathrm{g})$ and Cefuroxime $(30 \mu \mathrm{g})$. Oxoid sensitest agar plates were swabbed with cells from the bacteria stock solution, pre-adjusted to $0.5 \mathrm{McF}$ arland's turbidity standard. The discs were thereafter, carefully placed on the agar with a sterile forceps and incubated at $37^{\circ} \mathrm{C}$ for $24 \mathrm{~h}$. Zones of sensitivity was measured with a meter rule.

\section{Results}

A total of sixteen (16) bacteria were isolated from the street vended food in Amassoma community. Isolates identified in this studies were Salmonella spp (5), E coli (4) E coli 0157 (3) Proteus spp (2) and Klebsiella spp (2). The food samples on the other hand after enumeration revealed beans porridge to be containing (7) isolates, fried plantain (6) rice and stew (2) and no isolates for boiled Yam (Table 1). 
Table 1: Number of isolated organisms from food samples

\begin{tabular}{|l|l|l|l|l|l|l|l|}
\hline S/N & Source & $\begin{array}{l}\text { № of } \\
\text { Isolates }\end{array}$ & Salmonella spp & E coli & E coli 0157 & $\begin{array}{l}\text { Proteus } \\
\text { spp }\end{array}$ & $\begin{array}{l}\text { Klebsiella } \\
\text { spp }\end{array}$ \\
\hline 1 & $\begin{array}{l}\text { Cooked Rice and } \\
\text { stew }\end{array}$ & 3 & 0 & 1 & 2 & 0 & 0 \\
\hline 2 & Beans porridge & 7 & 3 & 1 & & 2 & 1 \\
\hline 3 & Boiled Yam & 0 & 0 & 0 & 0 & 0 & 0 \\
\hline 4 & Boiled Noodles & 1 & 0 & 1 & 0 & 0 & 0 \\
\hline 5 & Fried Plantain & 5 & 2 & 1 & 1 & $\mathbf{3}$ & 1 \\
\hline
\end{tabular}

The antibiotic susceptibility of the isolated bacteria revealed that Augmentin, Ceftazidine and Cefuroxime where completely resistant to all the bacteria tested. Implying that these antibiotics are not relevant in the treatment of diseases caused by these organisms. Other antibiotics show varying degree of susceptibility with ciprofloxacin showing the highest, whereas others were intermediate and weak. However Proteus spp in plate 2 is resistant to ciprofloxacin (Table 2)

Table 2: Antibiotic susceptibility pattern of the sampled foods

\begin{tabular}{|c|c|c|c|c|c|c|c|c|c|c|c|c|c|c|c|c|}
\hline & \multicolumn{16}{|c|}{ Zones of sensitivity (mm) } \\
\hline \multirow{3}{*}{ 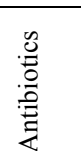 } & \multicolumn{5}{|c|}{ Salmonella spp } & \multicolumn{4}{|c|}{ E Coli } & \multicolumn{3}{|c|}{ E coli $\mathrm{O} 157$} & \multicolumn{2}{|c|}{ Proteus spp } & \multicolumn{2}{|c|}{ Klebsiella spp } \\
\hline & & & of & & & & lates & & & & & & & lates & № $\mathrm{C}$ & ates \\
\hline & 1 & 2 & 3 & 4 & 5 & 1 & 2 & 3 & 4 & 1 & 2 & 3 & 1 & 2 & 1 & 2 \\
\hline CAZ & $\mathrm{R}$ & $\mathrm{R}$ & $\mathrm{R}$ & $\mathrm{R}$ & $\mathrm{R}$ & $\mathrm{R}$ & $\mathrm{R}$ & $\mathrm{R}$ & $\mathrm{R}$ & $\mathrm{R}$ & $\mathrm{R}$ & $\mathrm{R}$ & $\mathrm{R}$ & $\mathrm{R}$ & $\mathrm{R}$ & $\mathrm{R}$ \\
\hline CRX & $\mathrm{R}$ & $\mathrm{R}$ & $\mathrm{R}$ & $\mathrm{R}$ & $\mathrm{R}$ & $\mathrm{R}$ & $\mathrm{R}$ & $\mathrm{R}$ & $\mathrm{R}$ & $\mathrm{R}$ & $\mathrm{R}$ & $\mathrm{R}$ & $\mathrm{R}$ & $\mathrm{R}$ & $\mathrm{R}$ & $\mathrm{R}$ \\
\hline GEN & 6 & 8 & 10 & 8 & 8 & 10 & 8 & 6 & 8 & 10 & 6 & 10 & 10 & $\mathrm{R}$ & 10 & $\mathrm{R}$ \\
\hline CXM & $\mathrm{R}$ & $\mathrm{R}$ & $\mathrm{R}$ & $\mathrm{R}$ & 20 & 12 & 14 & 12 & 12 & $\mathrm{R}$ & 10 & 12 & $\mathrm{R}$ & $\mathrm{R}$ & $\mathrm{R}$ & $\mathrm{R}$ \\
\hline OFL & 12 & 12 & 8 & 20 & 12 & 6 & 14 & 20 & 22 & 20 & 16 & 6 & 14 & 4 & 28 & 12 \\
\hline NIT & $\mathrm{R}$ & 4 & $R$ & 4 & 4 & 10 & 8 & 10 & 6 & 8 & 10 & 8 & 6 & 2 & 6 & 8 \\
\hline CPR & 24 & 12 & 16 & 24 & 30 & 32 & 20 & 26 & 30 & 26 & 20 & 16 & 24 & $\mathrm{R}$ & 20 & 4 \\
\hline AUG & $\mathrm{R}$ & $\mathrm{R}$ & $\mathrm{R}$ & $\mathrm{R}$ & $\mathrm{R}$ & $\mathrm{R}$ & $\mathrm{R}$ & $\mathrm{R}$ & $\mathrm{R}$ & $\mathrm{R}$ & $\mathrm{R}$ & $\mathrm{R}$ & $\mathrm{R}$ & $\mathrm{R}$ & $R$ & $\mathrm{R}$ \\
\hline
\end{tabular}

R- Resistant, CAZ-Ceftazidine, CRX-Cefuroxime, GEN-Gentamycin, CXM-Cefixime, OFL-Ofloxacin, NIT-Nitrofuratoin, CPRCiprofloxacin, AUG-Augmentin

\section{Discussion}

Food handling practices have been one of the leading causes of food borne illnesses globally especially in developing countries where food-borne illness are rampant. The study was designed to determine the bacteriological quality of highly patronised locally vended foods consumed in Amassoma community in Bayelsa state Nigeria. Food samples investigated were obtained from food vendors and stewards. Coliforms in general and $E$. coli in particular are indicators of faecal contamination, indicating that most street vended food sold around the community is contaminated. Thus the findings of (Thi et al, 2007; Smith et al, 2008; Feglo and Saky, 2012) correlates with these findings. Some food types promote the growth of certain types of bacteria than others as well as other inhibitory food chemicals that most have been used for preservation. The method of collection or serving to customers have also played a role in contamination. Most food vendors touch foods with bear hands and also handles dirty currency notes with the same hands without any concern for hygiene. This however has violated food safety practices (Bryan et al, 2003). A personal observation during sampling indicates that some vendors had their aprons stained with food and washing of aprons is not regular after previous usage, while some never wore aprons at all. Practice of washing cutlery in bowl of water in series and dipping the bowls and cutlery one after the other into the same water used several times without changing was also observed. Many indigenes defecate in rivers thereby contaminating the river. This ultimately reflects the high faecal coliform count in the present study especially with the isolation of E coli 0157 and Salmonella spp. The isolated organisms could likely increase the incidence of diarrhoea, typhoid and several community acquired infections especially among those with compromising immune system. Therefore, surveillance and monitoring should be of great concern in this community and the entire state. Finally this study also reveals the extent of antibiotic resistance and susceptibility of isolated organisms. 


\section{Conclusion}

The findings in this present study suggest that, food vendors and patronisers of street vended food should be adequately educated on the role of food in the transmission of disease. Government role on food control and safety should include mechanisms that will develop and maintain the necessary compliance policy to assure fair and equal application of legal sanctions to defaulters who sells un-safe food. On the other hand, Government should apply a well-structured, adequately resourced and efficient administered food control system to ensure that industry meets its obligation to provide safe food. Finally comprehensive and uniform reporting and data analysis of notifications of foodborne disease should be undertaken by Government and relevant agencies who should implement effective controls strategies and consequently act in response to the information supplied.

\section{Acknowledgement}

The authors wish to sincerely thank the staffs and management of Federal Medical Centre, Yenagoa, Bayelsa state for providing the facilities for analysis, also to Agbafor, Sunny Tarela and Owei, Kuronakigha for their support during sample collection and analysis.

\section{References}

[1]. Barro, N, Ouattara, C.A.T, Nikiema, A.P, Ouattara, A.S, Traoré, A.S (2002a). Evaluation de la qualite microbiologique de quelques aliment de me dans la ville de Ouagadougou au Burkina Faso. Cah Sante, 12: 369-374.

[2]. Barro, N, Nikiema, P, Ouattara, C.A.T, Traoré, AS (2002b). Evaluation de I'hygiene et de la qualité microbilogique de quelques aliments rue et les caracteristques de consommateurs dans les villes de Ouagadougou et de Bobo-Dioulasso (Burkina Faso). Rev. Sci. Tec.Sci. Santé, 25: 7-21.

[3]. Bauer, A.W, Kirby, W.M. Sheris, J.C. Turck, M (1996). Antibiotic susceptibility testing by a standardized single disc method. Am. J. Clin. Pathol. 45:149-158.

[4]. Bryan, M.B, Caroline, V, Madelon, F (2003). Safety of vendor-prepared foods: Evaluation of 10 processing mobile food vendors in Manhattan, Public Health Reports (118) 470-476.

[5]. Cheesbrough, M (2000). District Laboratory Practise in Tropical Countries, 4edn. Cambridge: Cambridge University Press, Part2 pp 434.

[6]. Chomvarin, C, Kotimanusvaniji, D Rhompruk (1993). Study on the correlation between the enterotoxin producing staphylococcus aureus isolated from prepared food and cooks. Srinagarind Hos. Med. j. (6)231-242.

[7]. Fang, T, Que-Kim, W, Chia-Wei, L, Min-Ju, H, Tzu-Hui, W (2003). Microbiological quality of $18^{\circ} \mathrm{C}$ ready-to-eat foods products sold in Tawian. International Journal of food micro-biology. 80 241-250.

[8]. Feglo, P, Sakyi, K (2012). Bacterial contamination of street vending food in Kumasi, Ghana. Journal of Medical and Biomedical Sciences 1(1): 1-8.

[9]. Gashaw A, Kassu A, Moges F, Tiruneh M, Huruy K (2008). Prevalence of Bacteria and Intestinal Parasites among Food handlers in Gondar Town, Northwest Ethiopia. J Health Popul Nutr.26:451-455.

[10]. Gillespie, I, Little, C, Mitchell, R (2000). Microbiological examination of cold ready to eat sliced meats from catering establishments in United Kingdom. J. Appl. Microbiol, 88: 467-474.

[11]. Käferstein F, Abdussalam M (1999). Food safety in the $21^{\text {st }}$ century. Bull World Health Organ; 77:347-51.

[12]. Mahale, D.P, Khade, R.G, Vaidya (2008). Microbiological analysis of street vended fruit juices from Mumbai city, India. Internet Journal of Food safety. 10: 31-34.

[13]. Mensah P, Yeboah-Manu D, Owusu-Darko K, Ablordey A (2002). Street foods in Accra, Ghana: How safe are they? Bull. World Health Organ. 80(7): 546-554.

[14]. Muleta, D. (2001). Bacteriological profile and holding temperature of street vended food from Addis Ababa. Int journal of environmental health research, 11, 95-105.

[15]. Omemu A.M, Edema M.O, Bankole M.O (2005). Bacteriological assessment of street vended ready to eat (RTE) vegetables and prepacked salad in Nigeria, Nig. J. Microbiol. 19(1-2): 497-504.

[16]. Smith SI, Alao F, Goodluck HT, Fowora M, Bamidele M, Omonigbehin E, Coker AO (2008). Prevalence of Salmonella typhi among food handlers from bukkas in Nigeria. Br J Biomed Sci. 65:158-60.

[17]. Tambekar, D, Jaiswal, V, Dhanorkar, D, Gulhane, P, Dudhane, M (2008). Identification of microbiological hazards and safety of ready-to-eat food vended streets of Amravati City, India. Journal of Applied Biosciences. 7, 195 - 201.

[18]. Thi T.H.V, George M, Taghrid I, Linh T.T, Peter J.C (2007). Detection of Salmonella spp. in retail raw food samples from Vietnam and characterization of their antibiotic resistance. Applied and Environmental Microbiology. 73 (21) 6885-6890.

[19]. WHO, (1996). Essential safety requirements for street vended foods. Food Safety Unit, Division of Food and Nutrition, WHOIFNUIFOSf96.7.

[20]. WHO (2003). Background document: The diagnosis, treatment and prevention of typhoid fever. Communicable Disease Surveillance and Response Vaccines and Biologicals, Department of Vaccines and Biologicals CH-1211 Geneva 27, Switzerland. pp 7-11.

[21]. Zeru, K, Kumie A (2007). Sanitary conditions of food establishments in Mekelle town, Tigray, north Ethiopia. Ethiop.J.Health Dev. 21:3-11. 